\title{
Francis Patrick Tally, M.D.
}

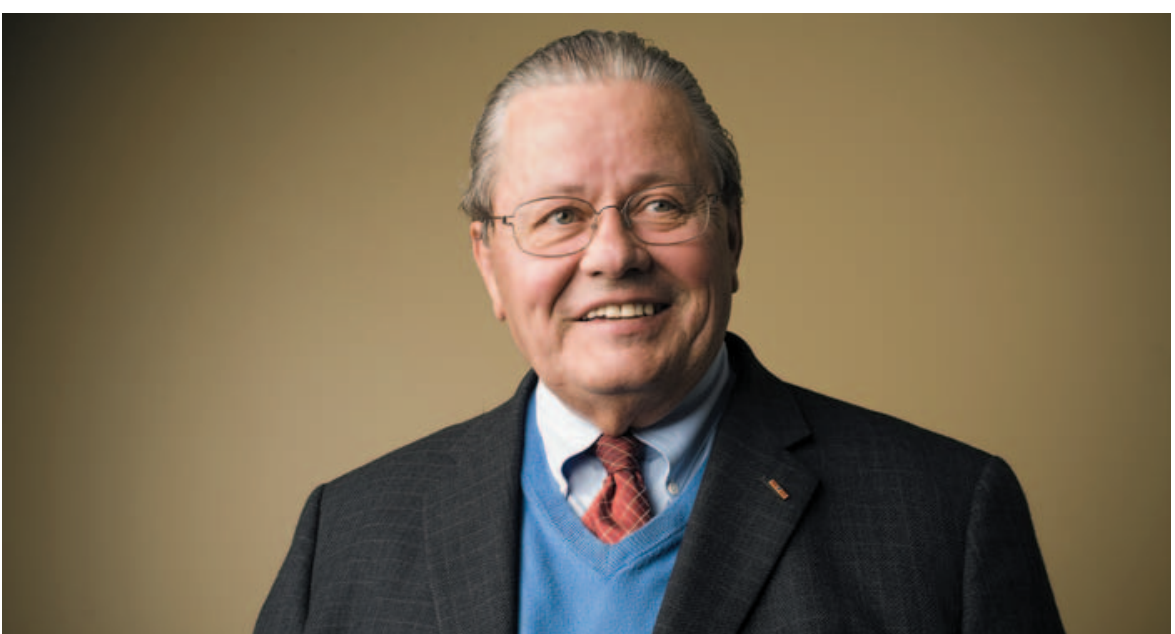

Frank Tally, the chief scientific officer of Cubist Pharmaceuticals who played a major role in bringing four antibacterial drugs (cefixime, piperacillin/tazobactam, daptomycin and tigecycline) into clinical use, passed away on Sunday 2 October 2006 at the age of 66 . Frank succumbed to an acute, overwhelming bacterial infection - infective endocarditis - leading his son, Kevin, to comment in his father's obituary in the Boston Globe that "bacteria put a hit out on him".

Born on 17 May 1940 in Providence, Rhode Island, Frank had an unmistakable New England accent. Although only 5 foot 7 inches tall he played varsity football in high school as an undersized offensive lineman who routinely outsmarted and outplayed his larger competitors - this will surprise no one who knew Frank! Repeated shoulder dislocations sidelined the self-described 'scrappy kid from Fruit Hill' in Providence, ending his footballplaying days. However, his physician brotherin-law Bud Curran suggested that he pursue a medical education, seeing in Frank a quick mind and incisive intelligence.

Frank graduated from Providence College and earned his M.D. at George Washington University School of Medicine. After medical school he served as a captain in the US Army Medical Corp and his service included a tour of duty in Vietnam, where he began to truly understand the clinical impact of infectious diseases. Although he was extremely proud of the medals he earned he didn't discuss his Vietnam service for 20 years after his return.
His time there made him realize that he would not be satisfied with a career as a 'genteel Rhode Island internist' and instead felt the need not just to practise medicine himself but to contribute something that would improve the practice of medicine in general.

Frank was a success in multiple endeavours - as an infectious disease physician, performing academic research in molecular microbiology, directing infectious disease research at a large pharmaceutical company and establishing and reinventing a biotech company. At Tufts University School of Medicine, Frank established himself as an expert not only on the clinical impact of bacterial drug resistance but also on the molecular mechanisms of resistance, mainly through studies on the anaerobic bacterium Bacteroides fragilis in collaboration with Michael Malamy.

After leaving Tufts and the academic world for industry in Pearl River, New York, in the late 1980s, it was under Frank's leadership at Lederle Labs (American Cyanamid) that tigecycline (Tygacil) was discovered and piperacillin/tazobactam (Zosyn/Tazocin) was successfully developed. It should be noted that piperacillin/ tazobactam, a drug for serious, hospitalbased infections, is currently the best-selling injectable antibiotic in the world.

Frank was a true 'thought leader' in the field of infectious disease research, drug discovery and development, not to mention the social and political issues that affect these fields. He was known for his ability to speak clearly, convincingly and directly at all times. Although Frank had a temper he channelled this negative energy into a positive passion to get the job done, whatever that job was. There was never any doubt about Frank's opinion on a particular issue, or why he held a certain point of view, and he unfailingly had the courage of his convictions.

The development of daptomycin (Cubicin), originally discovered (and subsequently shelved, ostensibly for safety reasons) by Eli Lilly \& Co. in the mid-1980s, was a case in point. Frank breathed new life into this old natural product; first appreciating its attributes and then devising a clinical development strategy that would minimize the putative safety concerns associated with the drug. This would eventually lead to the approval of daptomycin for the treatment of bacterial infections, including those caused by multidrug-resistant organisms.

Whether in industry or in academic institutions, it was a privilege to work with and learn from Frank, who taught us how to approach science-driven drug discovery ethically and zealously. Frank learned one key lesson in his career that will be carried forward: the drugs that he helped to bring to market - piperacillin/tazobactam, daptomycin and tigecycline - are all either natural products or semi-synthetic derivatives of natural products and to Frank's credit Cubist remains a company that is focused on novel natural-product-based drugs. Mike Bonney, the CEO of Cubist, stated it best when he said: "Frank's guiding voice and deep passion for fighting infectious disease will always be present in all who had the honour to work with him. He will be missed by all at Cubist and across the industry as a friend, mentor and a source of inspiration."

And even in death Frank has taught us all another important lesson: that the effective treatment of bacterial infections still remains a crucially unmet medical need.

Steven J. Projan

Wyeth Research, 87 Cambridge Park Drive, Cambridge, Massachusetts 02140, USA. doi: $10.1038 / \mathrm{nrd} 2233$

\section{Acknowledgements}

With thanks to Kevin J. Tally, Karen Bush, Nilda Jacobus and Cubist Pharmaceuticals. 